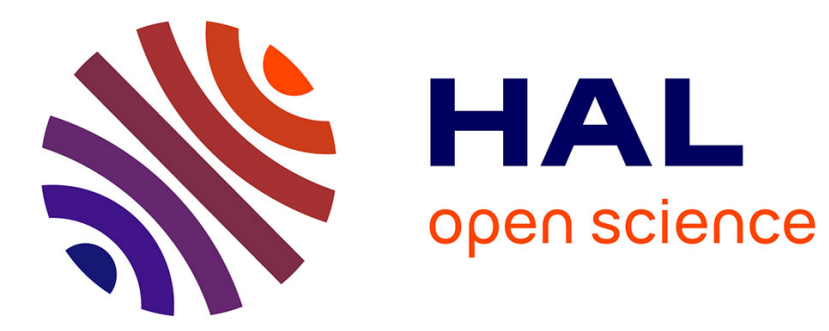

\title{
Alternative control of wild oat and canary grass in wheat fieldsby allelopathic plant water extracts
}

Muhammad Jamil, Zahid Ata Cheema, M. Naeem Mushtaq, Muhammad

Farooq, Mumtaz Akhtar Cheema

\section{To cite this version:}

Muhammad Jamil, Zahid Ata Cheema, M. Naeem Mushtaq, Muhammad Farooq, Mumtaz Akhtar Cheema. Alternative control of wild oat and canary grass in wheat fieldsby allelopathic plant water extracts. Agronomy for Sustainable Development, 2009, 29 (3), 10.1051/agro/2009007 . hal-00886508

\section{HAL Id: hal-00886508 https://hal.science/hal-00886508}

Submitted on 1 Jan 2009

HAL is a multi-disciplinary open access archive for the deposit and dissemination of scientific research documents, whether they are published or not. The documents may come from teaching and research institutions in France or abroad, or from public or private research centers.
L'archive ouverte pluridisciplinaire HAL, est destinée au dépôt et à la diffusion de documents scientifiques de niveau recherche, publiés ou non, émanant des établissements d'enseignement et de recherche français ou étrangers, des laboratoires publics ou privés. 


\title{
Alternative control of wild oat and canary grass in wheat fields by allelopathic plant water extracts
}

\author{
Muhammad JAMIL ${ }^{1}$, Zahid Ata CHEema ${ }^{2}$, M. Naeem MusHTAQ ${ }^{2}$, Muhammad FARooQ ${ }^{2 *}$, \\ Mumtaz Akhtar CHEEMA ${ }^{2}$ \\ ${ }^{1}$ Crop Sciences Institute, National Agricultural Research Centre, Islamabad 45500, Pakistan \\ ${ }^{2}$ Department of Agronomy, University of Agriculture, Faisalabad 38040, Pakistan
}

(Accepted 30 Jaunary 2009)

\begin{abstract}
The increasing concern about the toxicity of synthetic herbicides has boosted the search for eco-friendly and sustainable weed management practices. Allelopathic control of weeds has received great attention in recent years as a possible alternative for weed management. Here, a two-year field study was conducted to explore the herbicidal potential of sorghum water extract alone and in combination with water extracts of other allelopathic plants: eucalyptus, sesame, sunflower, tobacco and brassica, against wild oat (Avena fatua) and canary grass (Phalaris minor), two noxious weeds of wheat fields. Water extracts were applied twice 30 and 40 days after sowing. Our results show that application of sorghum and sunflower extracts at $12 \mathrm{~L} \mathrm{ha}^{-1}$ each was more effective than other combinations. This treatment reduced wild oat dry matter by $42-62 \%$, and canary grass by $36-55 \%$. Application of sorghum and sunflower at $6 \mathrm{~L} \mathrm{ha}^{-1}$ each increased the wheat grain yield by $89 \%$ during the first year, and by $35 \%$ during the second year. Application of the synthetic herbicide isoproturon at $1000 \mathrm{~g}^{-1}$ active ingredient ha ${ }^{-1}$ was more effective for weed inhibition and yield increase than allelopathic water extracts. Nevertheless, application of sorghum and sunflower at $6 \mathrm{~L} \mathrm{ha}^{-1}$ was economically more viable than the other treatments, with the highest marginal rate of return of $2824 \%$.
\end{abstract}

allelopathy / water extract / Phalaris minor / Avena fatua / wheat

\section{INTRODUCTION}

Wild oat and canary grass are two serious grassy weeds of wheat in many countries of the world, including Pakistan, each causing yield reduction of about $30 \%$ (Bell and Nalewaja, 1968; Malik and Singh, 1995; Hobbs et al., 1998). In Pakistan, important broad-leaved weeds in wheat are lambsquarters, field bindweed, broad-leaved dock, wild cress, wild pea and sweet clover, while narrow-leaved weeds comprise two grasses, viz. wild oat and canary grass (Tanveer and Ali, 2003). These two grasses are responsible for major yield loss in wheat and it is more cumbersome to control them than all other weeds.

Although effective chemical weed control methods are available, nonetheless, continuous use of the same type of herbicide also leads to the development of herbicide-resistant weed bio-types (Bhowmik and Inderjit, 2003). Several reports indicate the resistance of wild oat and canary grass to clodinafop-propargyl, diclofop-methyl, fenoxaprop-p-ethyl, isoproturon, fluazifop-p-butyl, haloxyfop-methyl, sethoxydim and tralkoxydim in various countries across the globe (Heap,

*Corresponding author: farooqcp@gmail.com
2007). In addition, herbicides pollute the soil, water and aerial environments and may enhance the disease risks (Ronald, 2000). Hence, concern regarding use of herbicides is growing worldwide.

Demand for organically produced commodities in the world is also increasing. The area under organic crops is more than 24 million hectares distributed in 100 countries, while the global market for organic foods is more than $\$ 23$ billion per annum and is growing rapidly (Roseboro, 2006). Scientists are looking for new ecological and natural approaches for weed management. The use of allelopathic plant water extracts for weed suppression offers a viable and pragmatic option. In our previous studies, sorghum water extract was found to be effective for weed suppression in many field crops including wheat (Cheema et al., 2000a), cotton (Cheema et al., 2000b), rice (Irshad and Cheema, 2004), maize (Cheema et al., 2004) and mungbean (Cheema et al., 2001). The extent of weed control was $35-49,40,37-41,18-50$ and $44 \%$ in wheat, cotton, rice, maize and mungbean, respectively, which is far less than what is achievable by herbicide use. This necessitates exploring some other means of exploiting allelopathic potential. Many plants other than sorghum, such as sunflower (Helianthus 
annuиs L.), brassica (Brassica campestris L.), eucalyptus (Eucalyptus camaldulensis D.), sesame (Sesamum indicum L.), rice (Oryza sativa L.) and tobacco (Nicotiana tabacum L.), etc., have also been found to possess allelopathic potential (Narwal, 1994; Purvis and Jones, 1990; Weston and Duke, 2003; Farooq et al., 2008). Duke and Laydon (1993) suggested that allelochemicals present in one plant water extract might act synergistically with the allelochemicals of another plant water extract. This indicates that efficacy of sorghum water extract can be improved by combining it with water extracts of other allelopathic plants. Hence, we evaluated the possible integration of sorghum with eucalyptus and sunflower water extracts and found that mixed application of sorghum, eucalyptus and sunflower water extracts gave $70 \%$ more weed suppression than sorghum water extract alone in wheat (Cheema et al., 2003).

These interesting findings require comprehensive studies on weed management using mixtures of different plant water extracts. To the best of our knowledge, no study has ever discovered the potential integration of allelopathic water extracts for wild oat and canary grass management in wheat. We hypothesized that mixed application of different allelopathic extracts can suppress the weeds better than application of a single plant extract.

\section{MATERIALS AND METHODS}

\subsection{General}

A two-year field study was conducted to investigate the herbicidal potential of sorghum water extract in combination with other plant water extracts against wild oat and canary grass in wheat at the Agronomic Research Area, University of Agriculture, Faisalabad-Pakistan. The experimental soil belonged to the Lyallpur Soil Series (Aridisol fine-silty, mixed, hyperthermic ustalfic, haplargid in USDA classification and Haplic Yermosols in FAO classification scheme). The $\mathrm{pH}$ of soil paste (pHs) and electrical conductivity (EC) of the saturation extract (ECe) were 7.8 and $1.2 \mathrm{dS} \mathrm{m}^{-1}$, respectively. The field was soaked with canal water ten days prior to land and seed bed preparation. Cross-cultivations, followed by double planking, were done to obtain a proper tilth. The wheat cultivar Punjab96 was used as a test crop. Sowing was done on 6th and 10th of November during the first and second year, respectively, using a seed rate of $110 \mathrm{~kg} \mathrm{ha}^{-1}$ in $25-\mathrm{cm}$ spaced rows with the help of a single row hand drill. Nitrogen, phosphorus and potassium were applied at 110,55 and $60 \mathrm{~kg} \mathrm{ha}^{-1}$, respectively. The fertilizers used were urea $(46 \% \mathrm{~N})$, diammonium phosphate $\left(18 \% \mathrm{~N}, 46 \% \mathrm{P}_{2} \mathrm{O}_{5}\right)$ and sulfate of potash $\left(50 \% \mathrm{~K}_{2} \mathrm{O}\right)$. All of the phosphorus and potassium and half of the nitrogen were applied as a basal dose, while the remaining half of the nitrogen was applied with the second irrigation. The first irrigation was carried out 20 days after sowing and subsequent irrigations were applied at different stages of crop growth according to crop requirements. In all, six irrigations were carried out. The experiment was laid out in a randomized complete block design (RCBD) with three replications. The plot size in both years was $7 \mathrm{~m} \times 2 \mathrm{~m}$.

\subsection{Preparation of plant water extracts and treatment application}

Based on a series of previous studies (Rizvi et al., 1992; Premasthira and Zungsontiporn, 1996; Cheema et al., 2003; Turk and Tawaha, 2003; Cheema et al., 2007) and availability of plants, the allelopathic plants for this study were selected. The herbage (stem + leaves) of the crop plants sorghum, sunflower, brassica, sesame and tobacco was harvested at full maturity, while leaves of eucalyptus were collected from trees growing on the farm. All the collected herbage was dried and stored under shelter to avoid possible leaching by rainwater. Each plant material was chopped with an electric fodder cutter into $2-\mathrm{cm}$ pieces. The chopped plant material was soaked in distilled water for $24 \mathrm{~h}$ at room temperature $\left(21^{\circ} \mathrm{C} \pm 2{ }^{\circ} \mathrm{C}\right)$ in a ratio of 1:10 (W/V) and was filtered through 10- and 60mesh sieves. The initial volume of distilled water for soaking was $10 \mathrm{~L}$ and after filtration the final volume of the leachate was $7 \mathrm{~L}$. These extracts were boiled at $100{ }^{\circ} \mathrm{C}$ to concentrate and reduce the extract volume by $95 \%$ for easy handling and application (Cheema and Khaliq, 2000). The same procedure was used for preparation of all plant water extracts. Boiling of extracts has no effect on the nature and type of allelochemicals present in the water extracts (Parveen, 2000). The concentrated plant water extract combinations and the herbicide were used as a post-emergence spray in the respective plots.

The volume of the spray $\left(300 \mathrm{~L} \mathrm{ha}^{-1}\right)$ was determined by calibration as described by Rao (1983). Spraying was done with a Knapsack hand sprayer fitted with a T-Jet nozzle maintaining a pressure of $207 \mathrm{kPa}$. Sorghum water extract was combined with water extracts of eucalyptus, sunflower, sesame, tobacco and brassica. Sorghum water extract was tank-mixed with extracts of eucalyptus, sunflower, sesame, tobacco and brassica, each at $6 \mathrm{~L} \mathrm{ha}^{-1}$. In one treatment sorghum and sunflower water extracts were combined at $12 \mathrm{~L} \mathrm{ha}^{-1}$ each. Sorghum water extract alone at $12 \mathrm{~L} \mathrm{ha}^{-1}$ was also used. All these water extract treatments were applied as foliar sprays twice at 30 and 40 days after sowing. Isoproturon at $1000 \mathrm{~g}$ active ingredient (a.i.) ha ${ }^{-1}$ (label dose) sprayed at 30 days after sowing and a weedy check (weeds were allowed to grow) were used as control.

\subsection{Procedure for recording data}

A quadrate measuring $50 \mathrm{~cm} \times 50 \mathrm{~cm}$ was randomly placed at two places in respective plots to record weeds. Weeds were cut from the ground surface and brought to the laboratory to record their biomass. The dry weight of weeds was determined by drying in an oven at $70{ }^{\circ} \mathrm{C}$ until constant weight was achieved. The number of productive tillers was counted; twenty tillers were selected at random from each plot to record number of spikelets per spike and number of grains per spike. To record grain yield, an area of $2 \times 2 \mathrm{~m}$ was harvested from the center of each plot and allowed to sun-dry for a week in the respective plot. The sun-dried crop was threshed manually. Grain weight from each treatment was measured in kilograms and later expressed in mega-grams per hectare $\left(\mathrm{Mg} \mathrm{ha}^{-1}\right)$. 
Table I. Effect of plant water extracts on dry matter of wild oat. ${ }^{1}$ Means with different letters in a column are significantly different at $P<0.05$; ${ }^{1 S}$ One spray at 30 days after sowing; ${ }^{2 S}$ Two sprays at $30+40$ days after sowing; $* \%$ inhibition compared with control; a.i. $=$ active ingredient.

\begin{tabular}{|c|c|c|c|c|c|}
\hline \multirow[t]{2}{*}{ Treatments } & & $\begin{array}{c}\text { Dry weight } \\
\left(\mathrm{g} \mathrm{m}^{-2}\right)\end{array}$ & $\begin{array}{c}\% \\
\text { inhibition* }\end{array}$ & $\begin{array}{c}\text { Dry weight } \\
\left(\mathrm{g} \mathrm{m}^{-2}\right)\end{array}$ & $\begin{array}{c}\% \\
\text { inhibition* }\end{array}$ \\
\hline & Dose $\left(\mathrm{ha}^{-1}\right)$ & \multicolumn{2}{|c|}{ Year I } & \multicolumn{2}{|c|}{ Year II } \\
\hline Sorghum & $12 \mathrm{~L}^{2 \mathrm{~S}}$ & $48.59 b^{1}$ & 21 & $14.73 \mathrm{~d}$ & 41 \\
\hline Sorghum + eucalyptus & $6 \mathrm{~L} \mathrm{each}^{2 \mathrm{~S}}$ & $44.51 \mathrm{~cd}$ & 28 & $16.73 \mathrm{~cd}$ & 32 \\
\hline Sorghum + sunflower & $6 \mathrm{~L} \mathrm{each}^{2 \mathrm{~S}}$ & $37.93 \mathrm{de}$ & 39 & $18.81 \mathrm{bcd}$ & 24 \\
\hline Sorghum + sesame & $6 \mathrm{~L} \mathrm{each}^{2 \mathrm{~S}}$ & $46.88 \mathrm{bc}$ & 24 & $20.03 \mathrm{bc}$ & 19 \\
\hline Sorghum + tobacco & $6 \mathrm{~L} \mathrm{each}^{2 \mathrm{~S}}$ & $53.08 \mathrm{~b}$ & 14 & $21.36 \mathrm{ab}$ & 14 \\
\hline Sorghum + brassica & $6 \mathrm{~L} \mathrm{each}^{2 \mathrm{~S}}$ & $46.72 \mathrm{bc}$ & 24 & $20.36 \mathrm{bc}$ & 18 \\
\hline Sorghum + sunflower & $12 \mathrm{~L} \mathrm{each}^{2 \mathrm{~S}}$ & $35.73 \mathrm{e}$ & 42 & $9.44 \mathrm{e}$ & 62 \\
\hline Isoproturon & $1000 \mathrm{~g} \mathrm{ai}^{1 \mathrm{~S}}$ & $1.40 \mathrm{f}$ & 98 & $0.81 \mathrm{f}$ & 97 \\
\hline Weedy check & - & $61.74 \mathrm{a}$ & - & $24.82 \mathrm{a}$ & - \\
\hline
\end{tabular}

Table II. Effect of plant water extracts on dry matter of canary grass. ${ }^{1}$ Means with different letters in a column are significantly different at $P<0.05 ;{ }^{1 S}$ One spray at 30 days after sowing; ${ }^{2 S}$ Two sprays at $30+40$ days after sowing; $* \%$ inhibition compared with control; a.i. $=$ active ingredient.

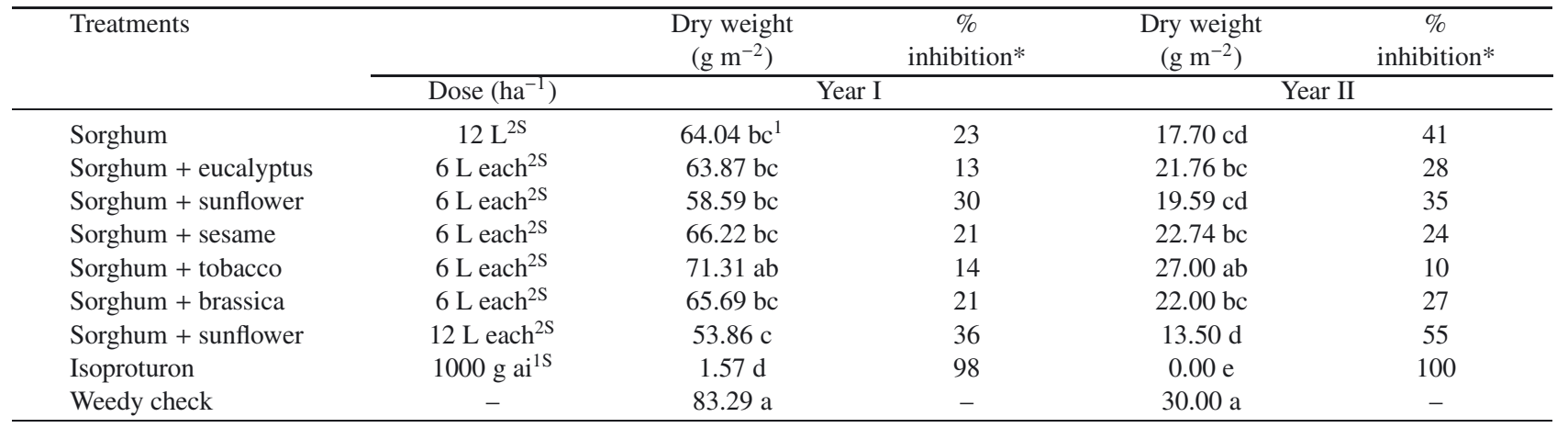

\subsection{Statistical and economic analyses}

Data collected were statistically analyzed by using the MSTATC statistical package (Anonymous, 1986). Analysis of variance was performed using Fisher's analysis of variance technique, while multiple comparisons among treatment means were made using the least significance difference test (LSD) at $P<0.05$ (Steel et al., 1997). Parallels were drawn to establish the relationship between weed biomass and grain yield using Microsoft Excel. Economic and marginal analyses were carried out on the basis of the mean values of the two years' data. Variable costs and prevailing market prices were taken following the procedure devised by CYMMIT (1988).

\section{RESULTS AND DISCUSSION}

\subsection{Effect of plant water extracts on growth of wild oat and canary grass}

All treatments significantly reduced the wild oat and canary grass dry matter compared with the weedy check during both experimental years (Tab. I, II). Two foliar sprays of sorghum + sunflower water extracts at $12 \mathrm{~L} \mathrm{ha}^{-1}$ each inhibited the dry matter of wild oat by 42 and $62 \%$, respectively, while two foliar sprays of sorghum water extract alone at $12 \mathrm{~L} \mathrm{ha}^{-1}$ reduced dry matter of wild oat by 21 and $41 \%$, respectively, in the first and second years of the study. Two foliar sprays of sorghum + sunflower at $12 \mathrm{~L} \mathrm{ha}^{-1}$ each reduced the dry weight of canary grass by 36 and $55 \%$ during the 1 st and 2 nd year, respectively. Nevertheless, the sorghum and sunflower water extract combination at $12 \mathrm{~L} \mathrm{ha}^{-1}$ each was better at suppressing weed dry matter than other combinations of sorghum water extract with eucalyptus, sesame, tobacco and brassica water extracts at $6 \mathrm{~L} \mathrm{ha}^{-1}$ each (Tabs. I, II).

Inhibition of the two important narrow-leaved weeds, canary grass and wild oat, of $42-62 \%$ and $36-55 \%$ with two foliar sprays of a mixture of sorghum and sunflower water extracts during both years of the study (Tab. I) under field conditions is a significant finding of this study. The other extracts: brassica, sesame, eucalyptus and tobacco, in combination with sorghum, were relatively less effective for weed suppression than the sunflower and sorghum combination. Likewise, suppression of wild oat was more than canary grass with the sorghum and sunflower combination. The inhibition of both weeds at the higher rate (12 $\mathrm{L} \mathrm{ha}^{-1}$ each) of the sorghum and sunflower combination was more than at their lower rate (i.e. $6 \mathrm{~L} \mathrm{ha}^{-1}$ ), which may be attributed to application of higher amounts of allelochemicals (Chon and Kim, 2004). The greater inhibition with the sorghum and sunflower combination is possibly due to their complementary phytotoxic effects on weeds (Duke and Laydon, 1993). The 


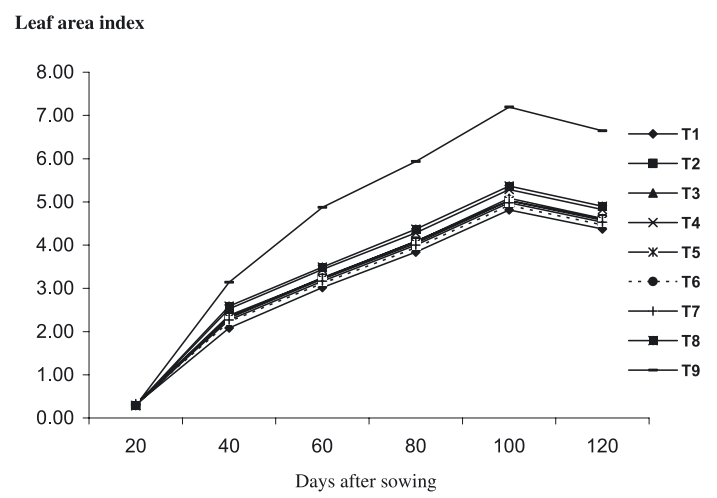

Figure 1. Effect of plant water extracts on leaf area index of wheat. Mean of two years. Periodic leaf area index from 20 to 120 days after sowing is given in the figure. Wheat leaf area index was substantially increased by the sole application of isoproturon (one spray) at $1000 \mathrm{~g}$ a.i. ha ${ }^{-1}\left(\mathrm{~T}_{9}\right)$ followed by application of sorghum + sunflower (water extracts), two sprays at $12 \mathrm{~L} \mathrm{ha}^{-1}$ each $\left(\mathrm{T}_{8}\right)$ and sorghum + sesame (water extracts), two sprays at $6 \mathrm{~L} \mathrm{ha}^{-1}$ each $\left(\mathrm{T}_{4}\right)$.

$\mathrm{T}_{1}=$ Weedy check; $\mathrm{T}_{2}=$ Sorghum + sunflower, two sprays at $6 \mathrm{Lha}^{-1}$ each; $\mathrm{T}_{3}=$ Sorghum + eucalyptus, two sprays at $6 \mathrm{~L} \mathrm{ha}^{-1}$ each; $\mathrm{T}_{4}=$ Sorghum + sesame, two sprays at $6 \mathrm{~L} \mathrm{ha}^{-1}$ each; $\mathrm{T}_{5}=$ Sorghum, two sprays at $12 \mathrm{Lha}^{-1} ; \mathrm{T}_{6}=$ Sorghum + brassica, two sprays at $6 \mathrm{~L} \mathrm{ha}^{-1}$ each; $\mathrm{T}_{7}=$ Sorghum + tobacco, two sprays at $6 \mathrm{~L} \mathrm{ha}^{-1}$ each; $\mathrm{T}_{8}=$ Sorghum + sunflower, two sprays at $12 \mathrm{~L} \mathrm{ha}^{-1}$ each; $\mathrm{T}_{9}=$ Isoproturon, one spray at $1000 \mathrm{~g}$ a.i. $\mathrm{ha}^{-1}$.

presence of phytotoxins in sorghum such as gallic acid, protocateuic acid, syringic acid, vanillic acid, p-hydroxybenzoic acid, p-coumaric acid, benzoic acid, ferulic acid, m-coumaric acid, caffeic acids, dhurrin, p-hydroxybenzaldehyde and sorgoleone has been reported by several authors (Guenzi and McCalla, 1966; Haskins and Gorz, 1985; Netzly and Butler, 1986; Nimbal et al., 1996). Sunflower has allelochemicals, viz. chlorogenic acid, isochlorogenic acid, $\alpha$-naphthol, scopolin and annuionones (Wilson and Rice, 1968; Macias et al., 1998, 2002; Anjum and Bajwa, 2005). More weed suppression from the combined use of sorghum and sunflower indicates the synergistic mode of allelochemicals present in sunflower and sorghum. Previously, Gerig and Blum (1991) reported that compounds in a mixture can replace each other on the basis of their biological exchange rate and may add to the potency of each other. Mixture of sorghum and sunflower water extracts might have enhanced their phytotoxic properties. Combined use of sorghum and sunflower water extracts is helpful for inhibition of wild oat and canary grass. This combination may be used for controlling these two grassy weeds in organic farming.

\subsection{Effect of plant water extracts on allometric response of wheat}

Leaf area index was improved by most of the treatments during both years (Fig. 1), except two sprays of sorghum and brassica water extract at $6 \mathrm{~L} \mathrm{ha}^{-1}$ each $\left(\mathrm{T}_{6}\right)$ and two sprays of sorghum and sunflower water extracts at $12 \mathrm{~L} \mathrm{ha}^{-1}$ each $\left(\mathrm{T}_{7}\right)$. Leaf area index reached a peak 100 days after sowing

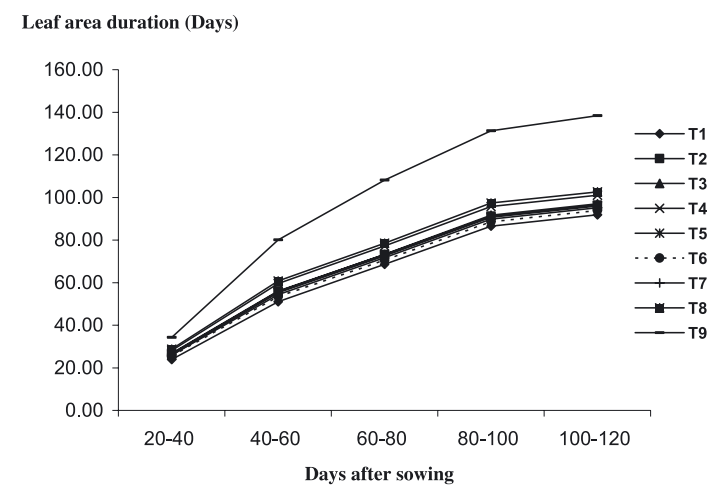

Figure 2. Effect of plant water extracts on leaf area duration of wheat. Mean of two years. Periodic leaf area duration from 20 to 120 days after sowing is given in the figure. Wheat leaf area duration was maximum with application of isoproturon (one spray) at $1000 \mathrm{~g}$ a.i. $\mathrm{ha}^{-1}\left(\mathrm{~T}_{9}\right)$, followed by application of sorghum + sunflower (water extracts), two sprays at $12 \mathrm{~L} \mathrm{ha}^{-1}$ each $\left(\mathrm{T}_{8}\right)$ and sorghum + sesame (water extracts), two sprays at $6 \mathrm{~L} \mathrm{ha}^{-1}$ each $\left(\mathrm{T}_{4}\right)$.

$\mathrm{T}_{1}=$ Weedy check; $\mathrm{T}_{2}=$ Sorghum + sunflower, two sprays at $6 \mathrm{Lha}^{-1}$ each; $\mathrm{T}_{3}=$ Sorghum + eucalyptus, two sprays at $6 \mathrm{~L} \mathrm{ha}^{-1}$ each; $\mathrm{T}_{4}=$ Sorghum + sesame, two sprays at $6 \mathrm{~L} \mathrm{ha}^{-1}$ each; $\mathrm{T}_{5}=$ Sorghum, two sprays at $12 \mathrm{~L} \mathrm{ha}^{-1} ; \mathrm{T}_{6}=$ Sorghum + brassica, two sprays at $6 \mathrm{~L} \mathrm{ha}^{-1}$ each; $\mathrm{T}_{7}=$ Sorghum + tobacco, two sprays at $6 \mathrm{~L} \mathrm{ha}^{-1}$ each; $\mathrm{T}_{8}=$ Sorghum + sunflower, two sprays at $12 \mathrm{~L} \mathrm{ha}^{-1}$ each; $\mathrm{T}_{9}=$ Isoproturon, one spray at $1000 \mathrm{~g}$ a.i. ha ${ }^{-1}$.

then declined. Sorghum + sunflower at 6 or $12 \mathrm{~L}$ each $\left(\mathrm{T}_{4} \&\right.$ $\mathrm{T}_{8}$ ) appeared to be most effective in enhancing leaf area index among the plant water extract combinations during both the years. However, the label dose of isoproturon was at the highest during both years.

Likewise, leaf area duration of wheat was also influenced positively by most of the treatments; however, certain treatments did not affect leaf area duration (Fig. 2). The treatment combinations $\mathrm{T}_{4}$ and $\mathrm{T}_{8}$ (sorghum + sunflower extract at 6 or $12 \mathrm{~L}$ each) were the most effective treatments among the plant water extract combinations for improving leaf area duration during both the years. Isoproturon at $1000 \mathrm{~g}$ a.i. ha $\mathrm{ha}^{-1}$ was the best treatment with consistently greater leaf area duration than all other treatments. Leaf area duration represents the period of photosynthetic activity (Fig. 2). Crop growth rate was improved steadily by treatment combination $\mathrm{T}_{8}$ (sorghum + sunflower at $12 \mathrm{~L}$ each) during the whole period of study (Fig. 3). Isoproturon $\left(\mathrm{T}_{9}\right)$-treated plots showed more growth rate at 20-40 days after sowing, which declined subsequently (40-60, 60-80 days after sowing) and became equal to $\mathrm{T}_{4}$ (sorghum and sesame water extracts at $6 \mathrm{~L} \mathrm{ha}^{-1}$ each). Thereafter, crop growth rate again improved at 80-100 days after sowing.

Leaf area index, leaf area duration and crop growth rate were improved by the application of sorghum + sunflower at the higher rate (at $12 \mathrm{~L} \mathrm{ha}^{-1}$ each) and isoproturon was effective (Figs. 1-3). This indicates that treatments effectively suppressing the weeds could improve the wheat allometric response, possibly due to improved availability of minerals, water and light, which otherwise would be utilized by the weeds. 
Table III. Effect of plant water extracts on yield and yield components of wheat. ${ }^{1}$ Means with different letters in a column are significantly different at $P<0.05 ;{ }^{1 S}$ One spray at 30 days after sowing; ${ }^{2 \mathrm{~S}}$ Two sprays at $30+40$ days after sowing; ${ }^{*}$ Figures in parenthesis show $\%$ increase compared with control; a.i. = active ingredient.

\begin{tabular}{|c|c|c|c|c|c|c|c|c|c|c|c|}
\hline \multirow[t]{2}{*}{ Treatments } & \multicolumn{3}{|c|}{$\begin{array}{l}\text { Productive tillers } \\
\mathrm{m}^{-2}\end{array}$} & \multicolumn{2}{|c|}{ No. of grains spike ${ }^{-1}$} & \multicolumn{2}{|c|}{ Total biomass } & \multicolumn{2}{|c|}{$\begin{array}{l}\text { Grain yield } \\
\left(\mathrm{Mg} \mathrm{ha}^{-1}\right)\end{array}$} & \multicolumn{2}{|c|}{ Harvest index (\%) } \\
\hline & Dose $\left(\mathrm{ha}^{-1}\right)$ & Year I & Year II & Year I & Year II & Year I & Year II & Year I & Year II & Year I & Year II \\
\hline Sorghum & $12 \mathrm{~L}^{2 \mathrm{~S}}$ & $304.7 \mathrm{ef}^{1}$ & $248.0 \mathrm{bc}$ & $50.1 \mathrm{~cd}$ & 48.2 abcd & $12.3 \mathrm{bcd}$ & $10.6 \mathrm{ab}$ & $3.7 \mathrm{~cd}(32)^{*}$ & $3.8 \mathrm{~b}(46)$ & $27.5 c^{1}$ & $36.7 b^{1}$ \\
\hline Sorghum + eucalyptus & $6 \mathrm{~L} \mathrm{each}^{2 \mathrm{~S}}$ & $325.3 \mathrm{bcd}$ & $242.7 \mathrm{~d}$ & $50.2 \mathrm{bcd}$ & $48.0 \mathrm{bcd}$ & $13.5 \mathrm{abc}$ & $9.2 \mathrm{~cd}$ & $4.7 \mathrm{~b}(68)$ & $3.3 \mathrm{bc}(27)$ & $29.6 \mathrm{bc}$ & $35.6 \mathrm{~b}$ \\
\hline Sorghum + sunflower & $6 \mathrm{~L} \mathrm{each}^{2 \mathrm{~S}}$ & $342.30 \mathrm{~b}$ & $246.3 \mathrm{c}$ & $52.0 \mathrm{abc}$ & $49.3 \mathrm{abc}$ & $13.9 \mathrm{ab}$ & $9.9 \mathrm{bcd}$ & $5.3 \mathrm{ab}(89)$ & $3.5 \mathrm{bc}(35)$ & $34.9 \mathrm{abc}$ & $35.5 \mathrm{~b}$ \\
\hline Sorghum + sesame & $6 \mathrm{~L} \mathrm{each}^{2 \mathrm{~S}}$ & 321.3 cde & $237.3 \mathrm{e}$ & $50.8 \mathrm{abcd}$ & $47.4 \mathrm{~cd}$ & $13.2 \mathrm{abcd}$ & $9.4 \mathrm{bcd}$ & $4.5 \mathrm{bc}(61)$ & $3.3 \mathrm{bc}(27)$ & $38.1 \mathrm{ab}$ & $34.9 \mathrm{~b}$ \\
\hline Sorghum + tobacco & $6 \mathrm{~L} \mathrm{each}^{2 \mathrm{~S}}$ & $302.7 \mathrm{f}$ & $232.3 \mathrm{f}$ & $49.6 \mathrm{~d}$ & $46.7 \mathrm{~d}$ & $11.5 \mathrm{de}$ & $8.6 \mathrm{~d}$ & $3.5 \mathrm{~d}(25)$ & $2.9 \mathrm{~cd}(12)$ & $34.1 \mathrm{abc}$ & $35.5 \mathrm{~b}$ \\
\hline Sorghum + brassica & $6 \mathrm{~L} \mathrm{each}^{2 \mathrm{~S}}$ & $308.7 \mathrm{def}$ & $235.7 \mathrm{e}$ & $51.5 \mathrm{abcd}$ & $47.2 \mathrm{~cd}$ & $11.6 \mathrm{cde}$ & $8.7 \mathrm{~d}$ & $3.6 \mathrm{~cd}(29)$ & $2.9 \mathrm{~cd}(12)$ & $30.6 \mathrm{bc}$ & $33.8 \mathrm{~b}$ \\
\hline Sorghum + sunflower & $12 \mathrm{~L} \mathrm{each}^{2 \mathrm{~S}}$ & $338.0 \mathrm{bc}$ & $249.3 \mathrm{ab}$ & $52.2 \mathrm{ab}$ & $49.9 \mathrm{ab}$ & $14.0 \mathrm{ab}$ & $10.4 \mathrm{bc}$ & $4.5 \mathrm{bc}(61)$ & $3.8 \mathrm{~b}(46)$ & $31.3 \mathrm{bc}$ & $34.1 \mathrm{~b}$ \\
\hline Isoproturon & $1000 \mathrm{~g} \mathrm{ai}^{1 \mathrm{~S}}$ & $389.3 \mathrm{a}$ & $251.7 \mathrm{a}$ & $52.4 \mathrm{a}$ & $50.4 \mathrm{a}$ & $14.5 \mathrm{a}$ & $11.7 \mathrm{a}$ & 6.0 a (114) & 4.9 a (88) & $32.0 \mathrm{bc}$ & $36.6 \mathrm{~b}$ \\
\hline Weedy check & - & $296.0 \mathrm{f}$ & $236.3 \mathrm{e}$ & $49.8 \mathrm{~d}$ & $46.1 \mathrm{~d}$ & $10.4 \mathrm{e}$ & $7.1 \mathrm{e}$ & $2.8 \mathrm{~d}$ & $2.6 \mathrm{~d}$ & $42.1 \mathrm{a}$ & $42.2 \mathrm{a}$ \\
\hline
\end{tabular}

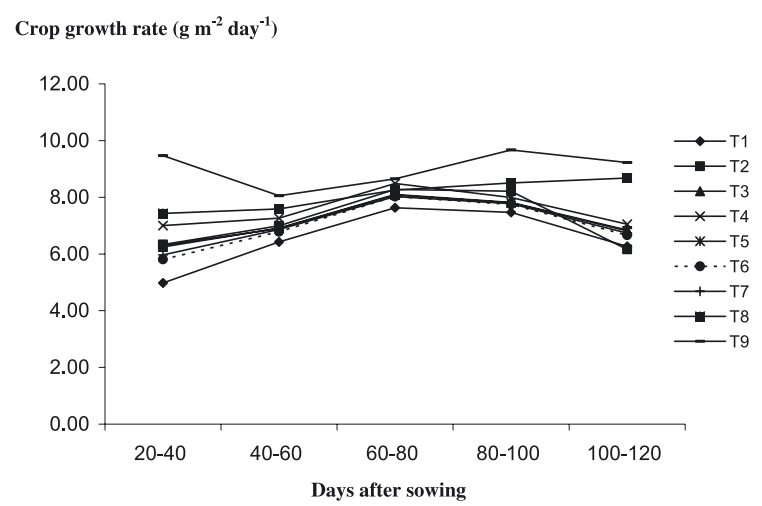

Figure 3. Effect of plant water extracts on crop growth rate of wheat. Mean of two years. Crop growth rate from 20 to 120 days after sowing is given in the figure. The highest crop growth rate was observed with application of isoproturon (one spray) at $1000 \mathrm{~g}$ a.i. ha ${ }^{-1}\left(\mathrm{~T}_{9}\right)$ followed by sorghum + sunflower (water extracts), two sprays at $12 \mathrm{~L} \mathrm{ha}^{-1}$ each $\left(\mathrm{T}_{8}\right)$.

$\mathrm{T}_{1}=$ Weedy check; $\mathrm{T}_{2}=$ Sorghum + sunflower, two sprays at $6 \mathrm{Lha}^{-1}$ each; $\mathrm{T}_{3}=$ Sorghum + eucalyptus, two sprays at $6 \mathrm{~L} \mathrm{ha}^{-1}$ each; $\mathrm{T}_{4}=$ Sorghum + sesame, two sprays at $6 \mathrm{~L} \mathrm{ha}^{-1}$ each; $\mathrm{T}_{5}=$ Sorghum, two sprays at $12 \mathrm{Lha}^{-1} ; \mathrm{T}_{6}=$ Sorghum + brassica, two sprays at $6 \mathrm{~L} \mathrm{ha}^{-1}$ each; $\mathrm{T}_{7}=$ Sorghum + tobacco, two sprays at $6 \mathrm{~L} \mathrm{ha}^{-1}$ each; $\mathrm{T}_{8}=$ Sorghum + sunflower, two sprays at $12 \mathrm{~L} \mathrm{ha}^{-1}$ each; $\mathrm{T}_{9}=$ Isoproturon, one spray at $1000 \mathrm{~g}$ a.i. ha ${ }^{-1}$.

\subsection{Effect of plant water extracts on yield and yield components of wheat}

The maximum number of productive tillers, number of grains, total biomass and grain yield were obtained from isproturon during both the years. Wheat grain yield was improved by all the treatments compared with control during both years except the combinations of sorghum + tobacco $\left(6 \mathrm{~L} \mathrm{ha}^{-1}\right.$ each $)$ and sorghum + brassica during both the years, and sorghum alone during year 1 (Tab. III). Combination of sorghum + sunflower (at $6 \mathrm{~L} \mathrm{ha}^{-1}$ each) increased the grain yield by $89 \%$ during the first year and was followed by sorghum + eucalyptus $\left(6 \mathrm{~L} \mathrm{ha}^{-1}\right.$ each) with a $68 \%$ increase in wheat grain yield, while in the second year sorghum + sunflower $\left(12 \mathrm{~L} \mathrm{ha}^{-1}\right.$ each $)$ and

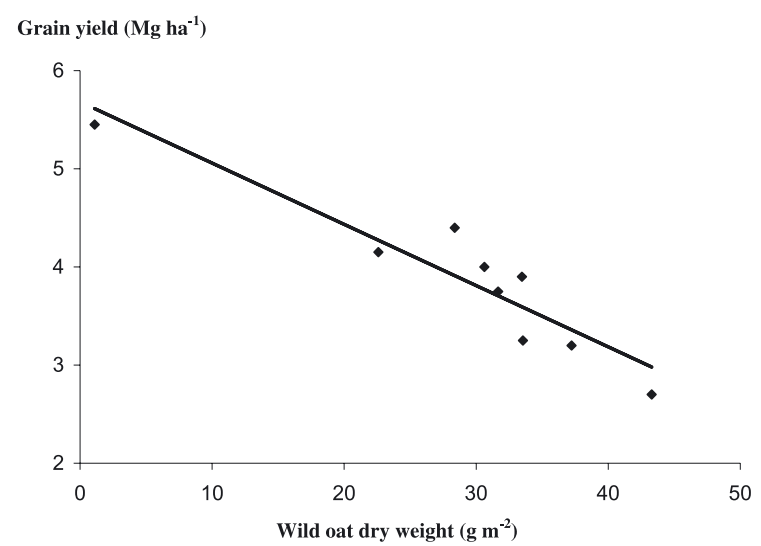

Figure 4. Relationship between wild oat dry weight and grain yield of wheat. Mean of two years.

$y=-0.0624 \times 5.6819 r^{2}=0.87$. Regression analyses of relationship between wheat yield and wild oat dry matter are given in the figure. The negative linear relationship shows that wheat yield decreased with the increase in wild oat dry matter production.

sorghum alone at $12 \mathrm{~L} \mathrm{ha}^{-1}$ increased wheat grain yield by $46 \%$. The label dose of the herbicide, isoproturon, increased grain yield by 114 and $88 \%$ during the first and second years, respectively. Productive tillers and number of grains per spike were improved in all the treatments except sorghum + tobacco.

The regression analyses showed that there was a negative relationship between wheat grain yield and dry matter production of wild oat and canary grass (Figs. 4,5 ). The coefficient of determination $(P<0.05)$ was 0.87 for wild oat and 0.84 for canary grass during both years of experimentation.

The weed inhibition is generally related to the increase in wheat grain yield; nonetheless, yield was higher during year I than year II, which seems the result of light rainfall, which kept the temperature mild during the grain-filling period (data not given). Moreover, the number of productive tillers and grain number were also higher during year I, both the traits contributing towards increased final yield (Tab. III). Weed suppression resulted in significant yield increase, as is confirmed by the negative correlation between wild oat dry weight and 
Table IV. Economic analysis*. ${ }^{1 S}$ One spray at 30 days after sowing; ${ }^{2 S}$ Two sprays at $30+40$ days after sowing; @ = at the rate of; PKR = Pakistan rupees (1 US Dollar $=80 \mathrm{PKR}) ;$ a.i. = active ingredient; * Mean of two years.

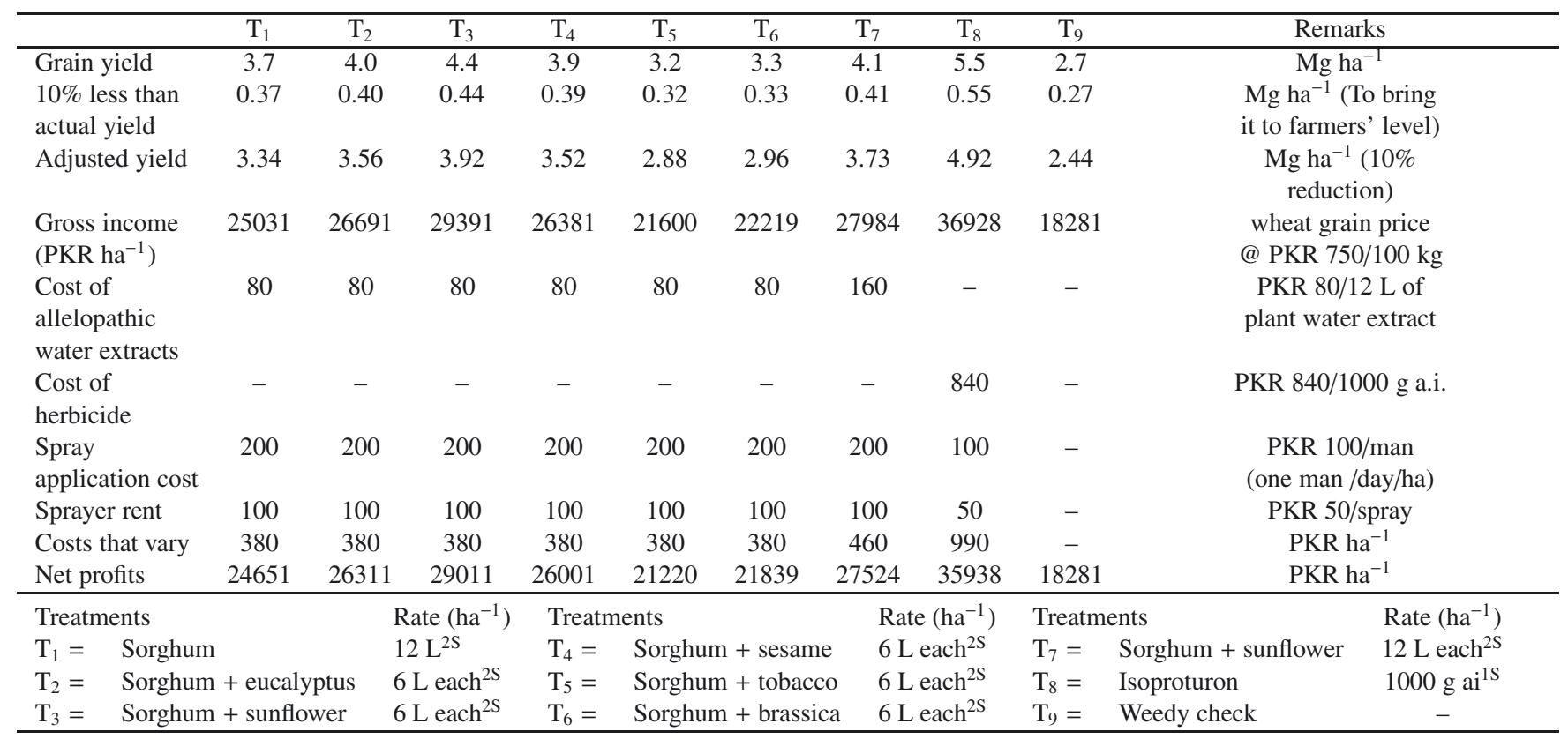

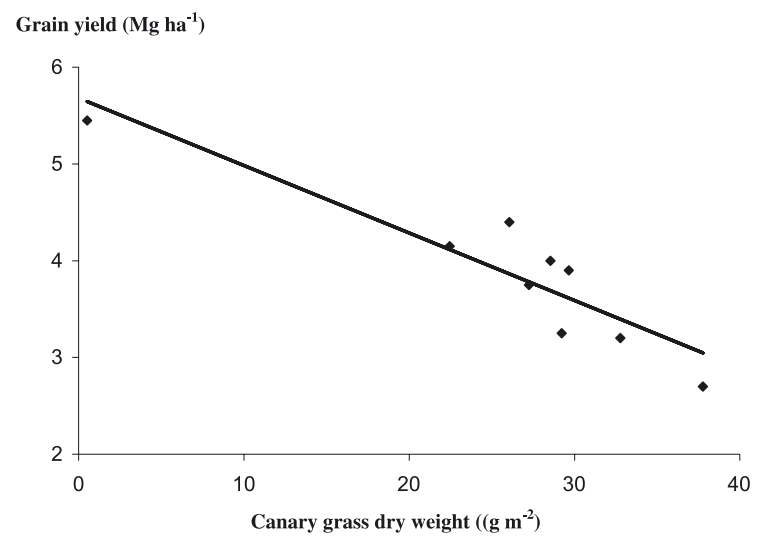

Figure 5. Relationship between canary grass dry weight and grain yield of wheat. Mean of two years.

$y=-0.0698 \times 5.6823 r^{2}=0.84$. Regression analyses of relationship between wheat yield and wild oat dry matter are given in the figure. The negative linear relationship shows that wheat yield decreased with the increase in canary grass dry matter production.

wheat grain yield (Fig. 4), and canary grass dry weight and wheat grain yield (Fig. 5). Less grain yield in all treatments except control during year II may be assigned to the allelopathic effects of the preceding sunflower crop in the field (data not given). Previously, Batish et al. (2002) reported that soil from sunflower fields was rich in phenolics, which reduced the stand establishment, growth and yield of the crop following sunflower. It is worth noting that the weed inhibition with sorghum + sunflower at $6 \mathrm{~L} \mathrm{ha}^{-1}$ each was less (32-33\%) than application of sorghum + sunflower at the higher rate (at
$12 \mathrm{~L} \mathrm{ha}^{-1}$ each) (46-52\%); nevertheless, the corresponding increase in yield was 89 and $61 \%$ at the lower and higher rates of sorghum + sunflower, respectively, during year I (Tab. II).

\subsection{Economic and marginal analyses}

All the treatments produced significantly higher net profits compared with control (Tab. IV). Among the allelopathic water extract combinations, sorghum + sunflower extracts at $6 \mathrm{~L} \mathrm{ha}^{-1}$ each provided higher net profits: PKR 29011 (1 US Dollar equals 80 PKR), followed by sorghum + sunflower at $12 \mathrm{~L} \mathrm{ha}^{-1}$ each (with PKR 27524 net returns). According to marginal analysis, sorghum + sunflower at $6 \mathrm{~L} \mathrm{ha}^{-1}$ was the best treatment, with a $2824 \%$ marginal rate of return. All other treatments were dominated due to either increasing costs that vary or the lower net profits (Tab. V). However, the label dose of isoproturon gave the highest net profits (PKR 35938) and a good marginal rate of return $(1588 \%)$.

Suitability of any treatment ultimately lies in its economic returns and the costs involved, and also its impact on the environment. Sorghum and sunflower water extracts at $6 \mathrm{~L} \mathrm{ha}^{-1}$ each appeared to be the most economical treatment among the water extract combinations, with fairly good net returns (PKR $29011 \mathrm{ha}^{-1}$ ) and the highest marginal rate of return $(2824 \%)$, by spending only PKR $380 \mathrm{ha}^{-1}$, while all other allelopathic plant water extract combinations were uneconomical. However, isoproturon at $1000 \mathrm{~g}$ a.i. ha ${ }^{-1}$ was also an economical treatment in terms of the highest net profits (PKR $35938 \mathrm{ha}^{-1}$ ) and a marginal rate of return of $1588 \%$ with an expenditure of PKR $990 \mathrm{ha}^{-1}$. Although two foliar sprays of sorghum + sunflower at $6 \mathrm{~L} \mathrm{ha}^{-1}$ each gave relatively less 
Table V. Marginal analysis*. ${ }^{1 S}$ One spray at 30 days after sowing; ${ }^{2 S}$ Two sprays at $30+40$ days after sowing; PKR = Pakistan rupees (1 US Dollar = 80 PKR); a.i. = active ingredient; $\mathrm{D}=$ Dominated due to less profits than the preceding treatment; * Mean of two years.

\begin{tabular}{|c|c|c|c|c|c|c|}
\hline Treatments & Dose $\left(\mathrm{ha}^{-1}\right)$ & $\begin{array}{l}\text { Total costs } \\
\text { that vary } \\
\left(\mathrm{PKR} \mathrm{ha}^{-1}\right)\end{array}$ & $\begin{array}{l}\text { Net profits } \\
\left(\text { PKR ha }^{-1}\right)\end{array}$ & $\begin{array}{c}\text { Marginal } \\
\text { cost }\end{array}$ & $\begin{array}{c}\text { Marginal net } \\
\text { profits } \\
\left(\mathrm{PKR} \mathrm{ha}^{-1}\right)\end{array}$ & $\begin{array}{l}\text { Marginal } \\
\text { rate of } \\
\text { return }(\%)\end{array}$ \\
\hline Weedy check & - & - & 18281 & - & - & - \\
\hline Sorghum + eucalyptus & $6 \mathrm{~L} \mathrm{each}^{2 \mathrm{~S}}$ & 380 & 26311 & - & - & $\mathrm{D}$ \\
\hline Sorghum + sesame & $6 \mathrm{~L} \mathrm{each}^{2 \mathrm{~S}}$ & 380 & 26001 & - & - & $\mathrm{D}$ \\
\hline Sorghum & $12 \mathrm{~L}^{2 \mathrm{~S}}$ & 380 & 24651 & - & - & $\mathrm{D}$ \\
\hline Sorghum + sunflower & $12 \mathrm{~L} \mathrm{each}^{2 \mathrm{~S}}$ & 460 & 27524 & - & - & $\mathrm{D}$ \\
\hline Isoproturon & $1000 \mathrm{~g} \mathrm{a.i.}^{1 \mathrm{~S}}$ & 990 & 35938 & 530 & 6928 & 1588 \\
\hline
\end{tabular}

economic returns than the herbicide, the allelopathic water extracts are environmentally friendly and fit into organic agricultural systems well.

\section{CONCLUSION}

Combined foliar application of sorghum and sunflower water extracts considerably suppressed the growth and dry matter production of wild oat and canary grass and was the most economical water extract treatment. This combination can be employed for weed management in organically grown wheat. Sorghum + sunflower water extracts at $6 \mathrm{~L} \mathrm{ha}^{-1}$ each are a better alternative to synthetic herbicides for wild oat and canary grass control in organic wheat production.

Acknowledgements: The authors of this article wish to extend their profound gratitude to the staff of the Weed Science \& Allelopathy Laboratory, Department of Agronomy, University of Agriculture, Faisalabad, Pakistan, for providing necessary assistance for conducting these experiments.

\section{REFERENCES}

Anjum T., Bajwa R. (2005) A bioactive annuionone from sunflower leaves, Phytochemistry 66, 1919-1921.

Anonymous (1986) MSTATC, Microcomputer Statistical Programme, Michigan State University, Michigan, Lansing, USA.

Batish D.R., Tung P., Singh H.P., Kohli R.K. (2002) Phytotoxicity of sunflower residues against some summer season crops, J. Agron. Crop Sci. 188, 19-24.

Bell A.R., Nalewaja J.D. (1968) Competition of wild oat in wheat and barley, Weed Sci. 16, 505-508.

Bhowmik P.C., Inderjit (2003) Challenges and opportunities in implementing allelopathy for natural weed management, Crop Prot. 22, 661-671.

Cheema Z.A., Khaliq A. (2000) Use of sorghum allelopathic properties to control weeds in irrigated wheat in a semi-arid region of Punjab, Agr. Ecosyst. Environ. 79, 105-112.

Cheema Z.A., Asim M., Khaliq A. (2000b) Sorghum allelopathy for weed control in cotton (Gossypium arboreum L.), Int. J. Agr. Biol. 2, $37-41$.
Cheema Z.A., Sadiq H.M.I., Khaliq A. (2000a) Efficacy of sorgaab (sorghum water extract) as a natural weed inhibitor in wheat, Int. J. Agr. Biol. 2, 144-146.

Cheema Z.A., Khaliq A., Akhtar S. (2001) Use of sorgaab (sorghum water extract) as a natural weed inhibitor in spring mungbean, Int. J. Agr. Biol. 3, 515-518.

Cheema Z.A., Khaliq A., Mubeen M. (2003) Response of wheat and winter weeds to foliar application of different plant water extracts of sorghum (S. bicolor), Pak. J. Weed Sci. Res. 9, 89-97.

Cheema Z.A., Khaliq A., Saeed S. (2004) Weed control in maize (Zea mays L.) through sorghum allelopathy, J. Sustain. Agr. 23, 73-86.

Cheema Z.A., Khaliq A., Abbas M., Farooq M. (2007) Allelopathic potential of different sorghum (Sorghum bicolor L. Moench) cultivars, Allelopathy J. 20, 167-178.

Chon S.U., Kim Y.M. (2004) Herbicidal potential and quantification of suspected allelochemicals from four grass crop extracts, J. Agron. Crop Sci. 190, 145-150.

CIMMYT (1988) From agronomic data to farmer recommendations: An economics training manual, Mexico, DF.

Duke S.O., Laydon J. (1993) Natural phytotoxins as herbicides, in: Duke S.O., Menn J.J., Plimmerm J.R. (Eds.), Pest control with enhanced environmental safety, ACS Symposium Series 524, American Chemical Society, Washington DC, pp. 111-121.

Farooq M., Jabran K., Rehman H., Hussain M. (2008) Allelopathic effects of rice on seedling development in wheat, oat, barley and berseem, Allelopathy J. 22, 385-390.

Gerig T.M., Blum U. (1991) Effects of mixtures of four phenolic acids on leaf area expansion of cucumber seedlings grown in Portsmouth B1 soil materials, J. Chem. Ecol. 17, 29-39.

Guenzi W.D., McCalla T.M. (1966) Phenolic acids in oat, wheat, sorghum and corn residues and their phytotoxicity, Agron. J. 58, 303-304.

Haskins F.A., Gorz H.J. (1985) Dhurrin and p-hydroxybenzaldehyde in seedlings of various sorghum species, Phytochemistry 24, 597-598.

Heap I. (2007) The international survey of herbicide resistant weeds, Online, Internet September 01, 2007, Available, http://www. weedscience.com.

Hobbs P.R., Sayre K.D., Monasterio J.I.O. (1998) Increasing wheat yields sustainably through agronomic means, NRG Paper 98-01, Mexico, DF.

Irshad A., Cheema Z.A. (2004) Effect of sorghum extract on management of barnyardgrass in rice crop, Allelopathy J. 14, 205-212. 
Macias F.A., Varela R.M., Torres A., Oliva R.M., Molinillo J.M.G. (1998) Bioactive norsesquiterpenes from Helianthus annuus with potential allelopathic activity, Phytochemistry 48, 631-636.

Macias F.A., Torres A., Galindo J.L.G., Varela R.M., Alvarez J.A., Molinillo J.M.G. (2002) Bioactive terpenoids from sunflower leaves cv. Peredovick, Phytochemistry 61, 687-692.

Malik R.K., Singh S. (1995) Littleseed canarygrass (Phalaris minor) resistance to isoproturon in India, Weed Technol. 9, 419-425.

Narwal S.S. (1994) Allelopathy in crop production (2nd ed.), Scientific Publishers, Jodhpur, India, p. 25.

Netzly D.H., Butler L.G. (1986) Roots of sorghum exude hydrophobic droplets containing biologically active components, Crop Sci. 26, $775-780$.

Nimbal C.I., Pedersen J.F., Yerkes C.N., Weston L.A., Weller S.C. (1996) Phytotoxicity and distribution of sorgoleone in grain sorghum germplasm, J. Agr. Food Chem. 44, 1343-1347.

Parveen Z. (2000) Identification of allelochemicals in sorghum (Sorghum bicolor L.) and their effect on germination and seedling growth of wheat (Triticum aestivum L.), M.Sc. thesis, Department of Chemistry, Univ. Agric. Faisalabad, Pakistan.

Premasthira C., Zungsontiporn S. (1996) Releasing of allelopathic substances from sesame (Sesamum indicum L.) plant, Proceedings of the 7th sesame workshop, Thailand, pp. 1-10.

Purvis C.F., Jones D.P.D. (1990) Differential response of wheat to retained crop stubbles, Aust. J. Agr. Res. 41, 243-251.
Rao V.S. (1983) Principles of weed science (2nd ed.), Oxford and IBH Publishing Co., New Delhi, pp. 1-7.

Rizvi S.J.H., Mishra G.P., Rizvi V. (1992) Allelopathic effects of nicotine on maize: its potential application in crop rotation, Plant Soil 116, 289-291.

Ronald E. (2000) Hand book of chemical risk assessment: health hazards to humans, plants and animals (Vol. II), Lewis Publishers, Washington DC, USA.

Roseboro K. (2006) The organic food handbook: a consumer's guide to buying and eating organic food, Basic Health Publications, Laguna Beach, CA, p. 9.

Steel R.G.D., Torrie J.H., Dickey D. (1997) Principles and procedures of statistics: a biometrical approach (3rd ed.), McGraw Hill Book Co., Inc. New York.

Tanveer A., Ali A. (2003) Weeds and their control, Higher Education Commission, Islamabad, Pakistan, pp 16-18.

Turk M.A., Tawaha A.M. (2003) Allelopathic effect of black mustard (Brassica nigra L.) on germination and growth of wild oat (Avena fatua L.), Crop Prot. 22, 673-677.

Weston L.A., Duke S.O. (2003) Weed and crop allelopathy, Crit. Rev. Plant Sci. 22, 367-389.

Wilson R.E., Rice E.L. (1968) Allelopathy as expressed by Helianthus annuus and its role in old field succession, Bull. T. Bot. Club 95, $432-448$. 